\title{
Hippophae salicifolia D. Don: A Miraculous Species Less Known in Europe
}

\section{Lucian DINCA ${ }^{1}$, Liviu HOLONEC ${ }^{2 *}$, Carmen SOCACIU ${ }^{2}$, Florin DINULIC $\breve{A}^{3}$, Cristinel CONSTANDACHE ${ }^{1}$, Tatiana BLAGA ${ }^{1}$, Adrian PETICILA $\breve{A}^{4}$}

\author{
${ }^{I}$ National Forest Research-Development Institute "Marin Dracea", 13 Closca, 500035 Brasov, \\ Romania;dinka.lucian@gmail.com; cicon66@yahoo.com; tatiana.blaga@yahoo.com \\ ${ }^{2}$ University of Agricultural Sciences and Veterinary Medicine, 3-5 Calea Manastur, 400372 Cluj-Napoca, \\ Romania; lholonec@yahoo.com ( ${ }^{*}$ correspondingauthor); carmen.socaciu@usamvcluj.ro \\ ${ }^{3}$ Transilvania University of Brașov, Faculty of Silviculture and Forest Engineering, 1 Șirul Beethoven, \\ 500123 Brașov,Romania; dinulica@unitbv.ro \\ ${ }^{4}$ University of Agronomic Sciences and Veterinary Medicine, Faculty of Horticulture, 59 Marasti Blvd., District 1, \\ 011464 Bucharest, Romania; apeticila@gmail.com
}

\begin{abstract}
Hippophae salicifolia is an Euro-Asian species used in many industries, from medicine to cosmetics, nutrition, or soil sciences (enriching degraded fields, diminishing soil erosion, preventing and treating diseases). The purpose of this study was to analyse the culture of this species in Europe together with the chemical content of its fruits. In order to achieve this, Hippophae salicifolia seeds were sown in greenhouses, seedlings were planted in fields, while the fruits were harvested and analysed both fresh, as well as after preservation for 1 year and 5 months. The properties of $H$. salicifolia fruits were also compared with the fruits of Hippophae rhamnoides, both fresh and preserved for 7 months. The analysis have shown that fresh fruits contain an average quantity of $31 ; 811$ and $231 \mathrm{mg} / 100$ total carotenoid, polyphenol, and ascorbic acid, respectively. The vitamin $\mathrm{C}$ content was much higher than that observed for $H$. rhamonides. If kept in adequate conditions, $H$. salicifolia fruits lose only a small amount of vitamin $\mathrm{C}$ and exhibit a vitamin $\mathrm{C}$ content $(224 \mathrm{mg} / 100 \mathrm{~g})$ superior to the fresh fruit of $H$. rhamonides $(100-150 \mathrm{mg} / 100 \mathrm{~g}$ ). By comparing the chemical characteristics of H. salicifolia and H. rhamnoides fruits preserved over a long period of time, a higher concentration of vitamin $\mathrm{C}$ was observed in $H$. salicifolia, while the differences between the other chemical characteristics were insignificant. The obtained results strongly suggest that $H$. salicifolia can be successfully cultured in Europe, while its exceptional fruit qualities can be capitalised on by a variety of industries.
\end{abstract}

Keywords: Vitamin C; sea buckthorn; seedlings; polyphenol

\section{Introduction}

Hippophae genus (Elaeagnaceae family) is considered to contain seven species, one of which is Hippophae salicifolia D. Don (Geetha and Asheesh, 2011; Pant et al., 2014). H. salicifolia is a resistant shrub with falling leaves from the mountain regions of China and Russia (Gupta and Ahmed, 2010), with a large but uneven distribution in Euro-Asia, namely between 27 and $69^{\circ} \mathrm{N}$ latitude and $7^{\circ} \mathrm{W}$ and $122^{\circ} \mathrm{E}$ longitude (Pant et al., 2014).
H. salicifolia spreads naturally at altitudes between 2000$3600 \mathrm{~m}$ in Euro-Asia, especially in Central and East Asia, in the Himalayan region around Pakistan, Nepal, and East India (Uprety et al., 2010). This species grows naturally on sandy soils in areas with a cold climate and can resist temperatures between $-43{ }^{\circ} \mathrm{C}$ and $+40{ }^{\circ} \mathrm{C}$. It is also highly resistant to drought (Yao and Tigerstedt, 1994). However, optimal conditions include average annual temperatures between 4.7 and $15.6{ }^{\circ} \mathrm{C}$ and with annual average precipitation of 250-800 $\mathrm{mm}$ (Basistha et al., 2009). 
$H$. salicifolia prefers to grow in conditions of low humidity, alluvial gravels, wet landslips, and riversides. However, it can also grow in arid to wet conditions (Yao and Tigerstedt, 1994). Reproduction occurs through suckers (Airi et al., 2009), while natural regeneration through seeds is scarce (Sankhyan et al., 2005). Seeds are viable for 2 years, while freshly harvested seeds enter a period of physiological dormancy (Singh et al., 2008; Gupta et al., 2011b). The leaves are alternate, narrow, and lanceolate with a greyish appearance (Synge, 1974). The male and female plants are similar in morphology. Differences are only observed after 3-4 years of growth and only during blooming (Gupta et al., 2012).

$H$. salicifolia has a number of important characteristics: controls soil erosion, creates a proper habitat for wild fauna, is resistant in severe meteorological conditions, and develops a rich rootlet system, even on scarce soils, by fixing nitrogen in the soil (Gupta and Ahmed, 2010). Furthermore, this species is thought to improve the soil's fertility and can regenerate degraded fields (Huxley, 1992; Airi et al., 2009). It can also be found on riverbanks, lakeshores, steep slopes, and other susceptible terrains (Basistha et al., 2009). The species has a considerable importance not only for increasing soil fertility in fields with high slopes where it prevents erosion and landslides, but also as firewood and as forage (Rongsen, 1992).

Some studies have suggested that this species is a potential source of bioactive antimicrobial agents and could be used as a natural preservative and for nutraceutical formulations (Gupta et al., 2011a). The leaves and seeds has a higher total phenolic content, comparing to other sea buckthorn species (Lu, 1992), as well leaves showed antiinflammatory properties (Padwad et al., 2006). During the last year, extracts from this plant were used in the USA as an food supplement (Saikia and Handique, 2012). This species contains a series of secondary metabolites, including carotenoids, flavonoids, tocopherols, sterols, unsaturated lipids, vitamin $\mathrm{C}$ and tannins. These compounds are well documented to have antioxidant, antitumor (Matheus and MacLeod, 1994; Singh et al., 2010), hepato-protective as well as immunomodulatory and anti-stress properties (nutritive, therapeutic, pharmaceutical, and cosmetic properties (Kaushal et al., 2013). A previous study demonstrated that the seeds of $H$. salicifolia have a greater antioxidant capacity than the leaves (Saikia and Handique, 2012).

The fruits of $H$. salicifolia have higher quantities of vitamin $\mathrm{C}$ and flavonoids, while the seeds represent between 3.4 and $4.1 \%$ of the fruit's mass (Ranjith et al., 2006). The fruits are edible and represent a rich source of vitamins, which are used in the preparation of local drinks (Gaur, 1999). Due to the high degree of perishability and acidic taste, the fruits cannot be consumed fresh and thus require rapid processing (Kaushal et al., 2013). In addition to its medicinal use, the fruits can be processed as juice and marmalade or used for adding flavour to lactic products due to its distinct taste (Gao et al., 2000; Saikia and Handique, 2012). The fruits are commonly used for preparing drinks by mixing other fruits or with the addition of sugar (Kaushal et al., 2013).
H. salicifolia seeds, juice, and pulp contain over 190 compounds (Gupta and Ahmed, 2010). Amongst them are the liposoluble vitamins $\mathrm{A}, \mathrm{K}$, and E, 22 fatty acids, 42 lipids, organic acids, amino acids, glucides, vitamins C, B1, and B2, folic acid, tocopherol, flavonoids, phenols, terpene, tannins, and 20 mineral elements; most of which are known for their beneficial health effects. Due to the high level of unsaturated fatty acids, the seeds are adequate for decreasing heart disease; this risk is also reduced by the presence of antioxidants, which prevent the oxidation of cholesterol (Gupta and Ahmed, 2010). The linolenic acids are also useful role in the treatment of rheumatoid arthritis, multiple sclerosis, psoriasis, and lupus. In China and the former Soviet Republics, medicinal sea buckthorn was used to treat the harmful effects of radiation, mouth burns, inflammation, and gastric ulcers (Gupta and Ahmed, 2010). The oil from this species blocks ultraviolet rays and helps in regenerating tissues (Gupta and Ahmed, 2010). The sea buckthorn oil, leaves and bark are known for their medicinal properties and have been used in treating the symptoms of the high number of lipids in blood, gingivitis, eye, or skin diseases, as well as cardiovascular diseases (Yang et al., 2000; Saikia and Handique, 2012). In China and Russia, the fruits have been used for years as prime material in alimentation and medicine (Cheng et al., 2003; Saikia and Handique, 2012). In conclusion, $H$. salicifolia has a wide range of uses (Fig. 1).

Sea buckthorn (Hippophaërhamnoides L.) is much more studied than Hippophae salicifolia. It grows wildly in EuroAsia and has been domesticated, being cultivated especially in the Carpathian regions, showing a good adaptability to various climate conditions and extensive genetic variability. Also, sea buckthorn is well known for its large scale utilization in industry, pharmacology, forest and land rehabilitation provided by its unique rich biochemical composition, variety of species, fast fruiting, high productivity and ecological adaptation (Bal et al., 2011; Pop, 2013). In addition to producing juice extremely rich in vitamin C (up to $20 \mathrm{~g} / \mathrm{L}$ ) and flavonoids, sea buckthorn berries are used for edible and cosmetic oil production, especially in China, Russia, and, more recently, in Europe. Relatively high contents of oil are found in both kernels and berry pulp. The kernel oil is a significant source of tocopherols, tocotrienols, plant sterols, and carotenoids; it contains essential fatty acids such as linoleic acid (35-45\%) and $\alpha$-linolenic acid (20-36\%). Pulp oil is more saturated, as more than half of the fatty acids are palmitic and palmitoleic acids, esterified as triglycerides. The yellow or orange sea buckthorn berries are rich in bioactive compounds (i.e. carotenoid pigments with provitamin A activity, folatederivatives and phylloquinone, phenolics, unsaturated lipids, tocopherols and phytosterols), as well volatiles which contribute to the increasing interest for sea buckthorn utilisation for human nutrition and health promotion (Singh, 2005; Bal et al., 2011; Giuffrida et al., 2011). Fortyone different carotenoids have been reported in various cultivars, with zeaxanthin, beta-cryptoxanthin, and betacarotene as the predominant ones (Raffo et al., 2004; Andersson et al., 2009; Giuffrida et al., 2011), but also minor ones (lycopene and canthaxanthin) (Kallio et al., 2002; Yang and Kallio, 2005; Vescan et al., 2010). The 
476

presence of carotenoid esters has been also reported in sea buckthorn berries (Pintea et al, 2005; Parlog et al., 2009), but the identification and quantification of the individual carotenoid esters is poorly described, especially in Romanian varieties (ssp. carpatica) (Socaciu, 2008). Significant quantities of fruits of sea buckthorn are harvested annually from this species (169 t in the year 2016; Vasile et al., 2016), sometimes with numerous medicinal uses (Vasile et al., 2015). In Romania, white sea buckthorn is used in the ecological reconstruction of degraded fields (Constandache et al., 2016), or for planting in waste heaps (Dincă et al., 2011).

As such, the plant's high adaptability, characteristics and potential are the main reason for enterprising this study that intends to increase awareness for its benefits, characteristics rendered in well-analyzed numbers and recommended usages.

\section{Materials and Methods}

\section{Sea buckthorn seeds used}

Hippophae salicifolia seeds, native to China, were sowed in the year 2010 in the greenhouse at I.N.C.D.S. (National Forest Research-Development Institute) Braşov, Romania. The 3-year-old seedlings were planted in fields (Boloteşti nursery garden, Vidra Experimental Basis - I.N.C.D.S. Focsani, Romania). The first fructification occurred in the fifth year (2015). Based on the fruit's morphological (shape, measure) and organoleptic (taste, colour) characteristics, two main varieties were identified (noted as 1 and 2). Fruits were harvested from these varieties to determine their chemical properties:
$1=$ yellow-orange colour, medium size ellipsoidal seeds $(5-6 \mathrm{~mm} / 2-3 \mathrm{~mm})$, flavoured;

$2=$ bright red colour, small round seeds $(3-4 / 2-3 \mathrm{~mm})$.

Material from other I.N.C.D.S. Brasov H. salicifolia plantations was used for comparison. Fruits from the year 2015 were harvested, as well as $H$. rhamnoides fruits preserved for 7 months at a constant temperature of $-15^{\circ} \mathrm{C}$. The samples were analysed at the Forest Product Laboratory at Transylvania University, Braşov, Romania.

\section{Sowing and cultivating the species in fields}

The sowing can be performed in autumn, after harvesting the coarse fruits, or in spring with seeds extracted from the fruits and stratified. In the present case, sowing was performed in the spring, after stratification of seeds in the sand for 90 days at a temperature of $3{ }^{\circ} \mathrm{C}$. The sowing depth was $2 \mathrm{~cm}$, with a seed norm of $2 \mathrm{~g}$ per linear meter. Emergence occurred at approximately 20-30 days from dissemination. The optimal cultivation density was $30-40$ seedlings per linear metric. Sowing was performed in plastic caskets of $60 \times 40 \times 15 \mathrm{~cm}$.

The substratum in which sowing was performed was composed of a mixture of 1:1 peat and sand, and disposed in the caskets over a grovel layer $5 \mathrm{~cm}$ deep. Two types of peat were used: oligotrophic peat (35\% organic matter, $0.4 \%$ total $\mathrm{N}$ and $\mathrm{pH} 3.4-4$ ) and eutrophic peat (19\% organic matter, $0.62 \%$ total $\mathrm{N}$ and $\mathrm{pH} 7.10$ ). The mixture of blonde peat and sand had a $\mathrm{pH}$ of 4.14, while the mesotrophic and sand mixture had a pH of 6.91. Pricking out the obtained seedlings from the cuttings was performed in plastic pots, in a mixture of 2:1 common beech humus and sand, with a $\mathrm{pH}$ of 5.71 (Fig. 2). The adequate types of fertilisers were used.

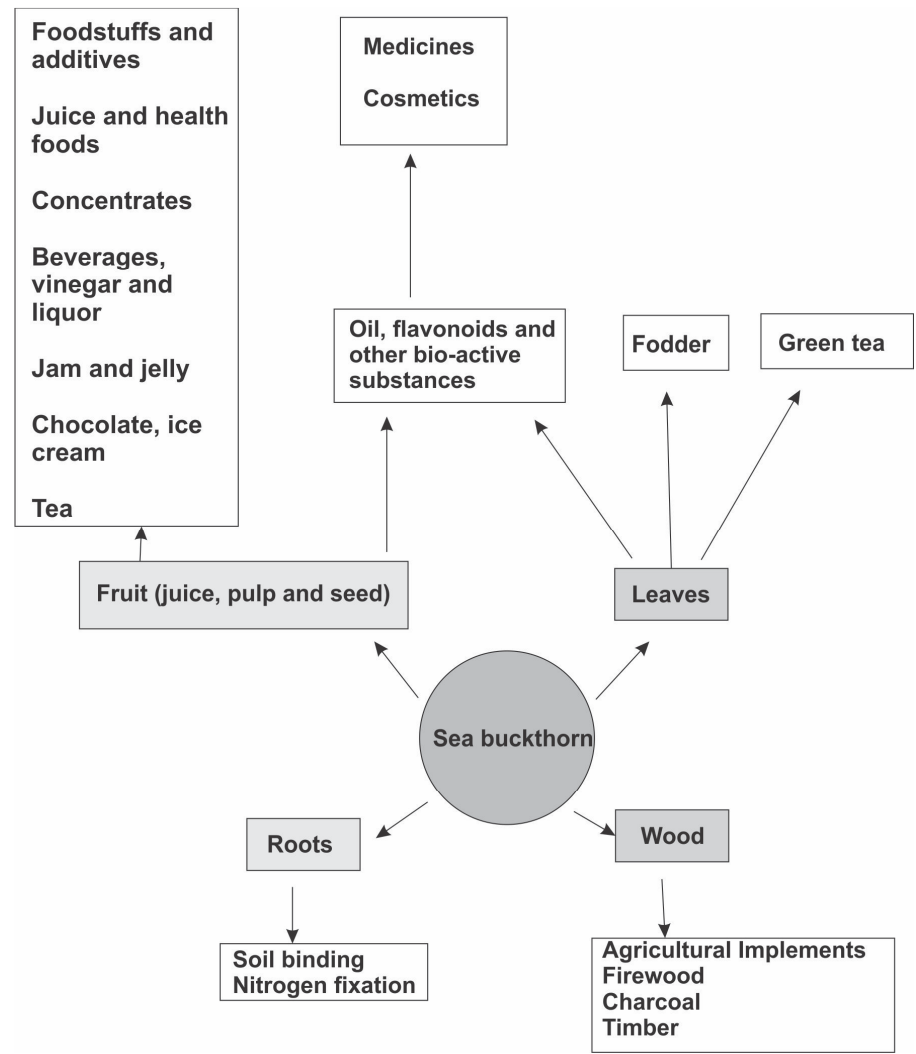

Fig. 1. Use of various parts of Hippophae salicifolia (Rajesh, 2009) 


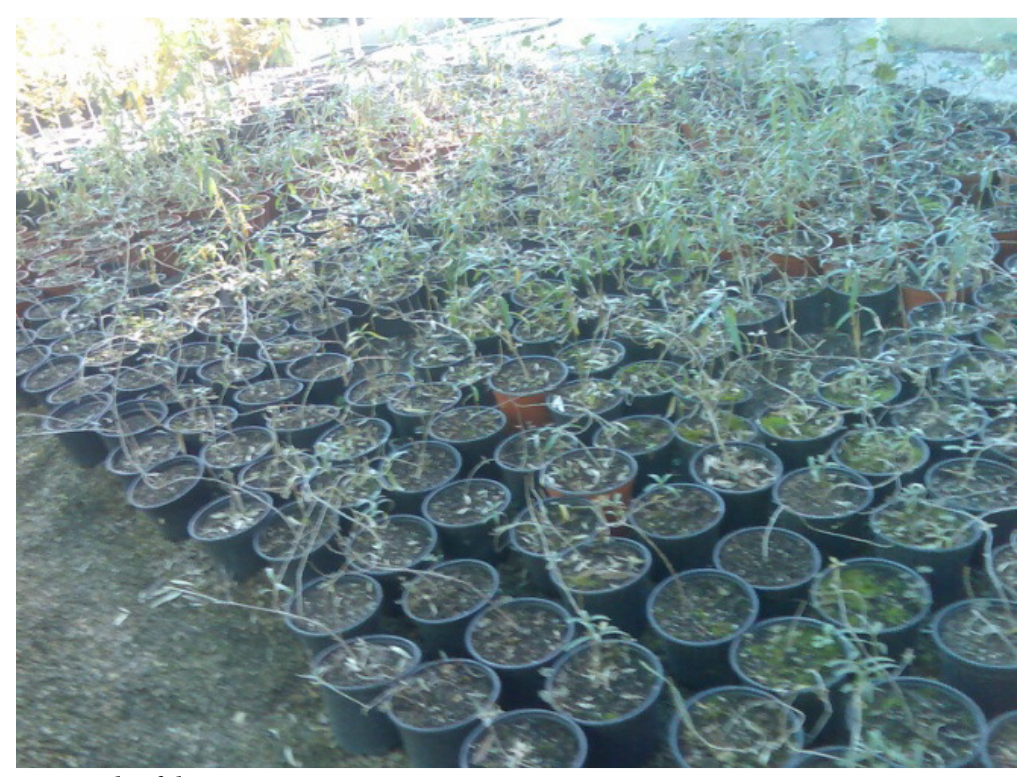

Fig. 2. One-year seedlings of H. salicifolia in the I.N.C.D.S. Braşov greenhouse

In terms of preventing disease and controlling harmful agents, the main problem that appeared in the installed cultures was provoked by Aphide (lice, flea) and the white greenhouse fly (Trialeurodes vaporariorum). To control these harmful agents, the insecticides were applied by alternative spraying.

Planting the seedlings in the field (Bolotești nursery garden) was performed at the beginning of April 2013, before the start of vegetation. The field was flat and field preparation consisted of cleaning vegetal remains and stones, deep ploughing $(25-30 \mathrm{~cm})$, followed by two discing. The soil was alluvial, with a reduced humus content, loamy texture, and granular-poliedric structure, with approximately $20-30 \%$ coarse fragments.

Seedling plantation was performed in common graves of $30 \times 30 \times 30 \mathrm{~cm}$ in a $2.5 \times 1.5 \mathrm{~m}$ schema, while the rows were oriented in the East-West direction. Seedlings with protected roots were planted in the grave from the recipient in which it was grown. Afterwards, maintenance was performed each year: soil mobilisation, which consisted of two hoeings per row and one furrow between the rows. The ratio of male to female specimens is 1:1 (which has determined the weak fructification). Normally, this ratio would be 1 male to 6-7 females.

\section{Chemical analyses}

After defrosting, total contents of water, soluble solids, lipids (including pro-vitamin A), vitamin C, invert sugar, and ash were determined for both sets of material. Humidity of the samples during quantified was $73 \%$.

The vitamin $\mathrm{C}$ content ( $\mathrm{mg}$ vitamin $/ 100 \mathrm{~g}$ fruits) was determined with the iodometric method (Kallner, 1987; Daviers et al., 1991), with extraction in $2 \% \mathrm{HCl}$ and potassium iodate N/1000 titration (Corlățeanu et al., 1975). The acidity (g acid malic/100 g fruits) was determined with the titrimetric method (Sinclair et al., $1945)$, and with $0.1 \mathrm{~N}$ sodium hydroxide titration (***, 2011) for juice obtained from the fruits. The total content of soluble solids was determined refractometrically (OECD, 2009), with an Optech hand-held refractometer. Inverted sugar was determined with the Ofne method (McDonald and Turcotte, 1946). The lipids and vitamin A extracts were obtained in petroleum ether with the Soxhlet apparatus, after the defrosted samples naturally achieved a humidity of $10.9 \%$. The ash was obtained through dry ashing in a muffle furnace at $550^{\circ} \mathrm{C}$ (Schuck et al., 2012).

Extraction of HS berries for spectrometry and chromatographic analysis. Aliquots of $10 \mathrm{~g}$ were taken in duplicate from each variety (V11, V12 and V21, V22 respectively). The extraction of unpolar components was done in a volume of $100 \mathrm{ml}$ mixture of chloroform: methanol $(2: 1, v / v)$. The samples were sonicated for $1 \mathrm{~h}$ and stirred for another $30 \mathrm{~min}$ using a magnetic stirrer in dark conditions. Further, all samples were centrifuged for $10 \mathrm{~min}$ at $2500 \mathrm{rpm}$ and $4{ }^{\circ} \mathrm{C}$. The pellet and supernatant were recovered. Afterwards, the pellet was re-extracted twice using the same procedure. The three supernatants were combined and then separated in a separation funnel using water to induce phase separation (lower lipophilic phase and upper hydrophilic phase). The lower chloroform phase was further concentrated under vacuum and kept in the freezer until analysis.

The UV-Vis spectral fingerprinting of HS extracts. UVVis spectra were recorded for each HS berty extract using a Jasco V 530 Spectrophotometer, in the range $300-550 \mathrm{~nm}$. There were identified the maximum wavelengths specific for the carotenoids and there were compared the fingerprints of the four samples (V11, V12, V21, V22). For qualitative evaluation, it was used the general formula (Britton et al., 1995).

Carotenoids (expressed in $\mathrm{mg} / \mathrm{g}$ berry $)=($ Absorbance $450 \mathrm{~nm} \times$ extract volume $\times$ dilution $\times 10000) /(2500 \times 100)$

UHPLC-DAD analysis of the HS extracts. For chromatographic analysis it was used a UHPLC-QTOF$\mathrm{ESI}^{+}$-MS Bruker Maxis Impact device (Dionex HPLC coupled with Bruker mass Spectrometer). For separation, a column Acquity BEH C18, $1.7 \mu \mathrm{m}, 2.1 \times 75 \mathrm{~mm}$ was used, with Run-to-run time set at $20 \mathrm{~min}$. Injection volume was $1 \mu \mathrm{l}$, column temperature $32^{\circ} \mathrm{C}$, flow: $0.1 \mathrm{ml} / \mathrm{min}$, with isocratic mobile phases: ACN/MeOH/IPA (45/50/5) + 
478

$0.1 \%$ FA. For diode array detection of carotenoids, there were chosen $280 \mathrm{~nm}, 340 \mathrm{~nm}, 445 \mathrm{~nm}$ and $475 \mathrm{~nm}$, for a possible identification of phenolics (phenolic acids absorbing at $280 \mathrm{~nm}$, flavonoids absorbing at $340 \mathrm{~nm}$, and carotenoids absorbing at 445 and $475 \mathrm{~nm}$, respectively).

For the adequate identification of carotenoids separated on the column, the optimal QTOF-ESI ${ }^{+}$-MS parameters were chosen: capillary voltage $3500 \mathrm{~V}$, drying gas flow 12 $1 / \mathrm{min}$, and drying temperature $300^{\circ} \mathrm{C}$. The $\mathrm{m} / \mathrm{z}$ values were identified, in the range 250-1000 Da. The control of the whole instrument and the data processing were done using the specific software TofControl 3.2, HyStar 3.2 and Data Analysis 4.1 (Bruker, Daltonics).

\section{Results}

\section{Cultivating the species in fields}

Better results were obtained with the eutrophic substratum, compared with the oligotrophic one.

The attachment was $95 \%$ and 3 years after plantation (2016), the keeping was $75 \%$. This decrease was caused by drought. Approximately $10 \%$ of the remaining specimens exhibited an abnormal vegetative state (dry sprouts, discolouration, and defoliation). The biometric characteristics of the culture (at 3 years) are the following: minimum height, $120 \mathrm{~cm}$; maximum height, $260 \mathrm{~cm}$; average height, $170 \mathrm{~cm}$; and crown diameter, $85-90 \mathrm{~cm}$ minimum and $200 \mathrm{~cm}$ maximum.

In 2014 and 2015, forming cuttings were applied, namely choosing the ax and 3-5 lateral branches that are best situated on the axe. Both branches as well as the axe were shortened by one-half or one-third based on the robustness of growth by trimming the axe from 30 to $30 \mathrm{~cm}$ with skeleton branches up to a height of $1.5-1.7 \mathrm{~m}$, considered suitable for the manual work of cutting and harvesting.

During the following spring (2016), fructification cutting was also performed, oriented mostly on the fruiting branches, so that the fruit was closer to the periphery of the crown. The sea buckthorn enters fructification in the second, third, or fourth year from plantation (Fig. 3). At the beginning, fructification is concentrated on the axe and at the base of skeleton branches. As the plants age, the fructification is directed towards the crown's periphery by cutting. Furthermore, the cuttings intend to evenly distribute the fructification branches, as well as their rejuvenation.

Afterwards, intervention of fructification formation is performed annually, so that they remain at a distance of 10$12 \mathrm{~cm}$ in less bright areas and $6-7 \mathrm{~cm}$ towards the crown's periphery. A part of the fructification formation is eliminated from the base, while another is cut in $1-1.5 \mathrm{~cm}$ snags. From the sprouting formed from the snags, the most vigorous and best-situated one is chosen to replace the fructification formation that fructified the previous year. This alternative replacement operation is repeated every year, based on the same principle. Fructification cutting is performed in the fall or spring, but can also be partially performed during the period of fruit maturation, when harvesting is performed by detaching the fructification branches.

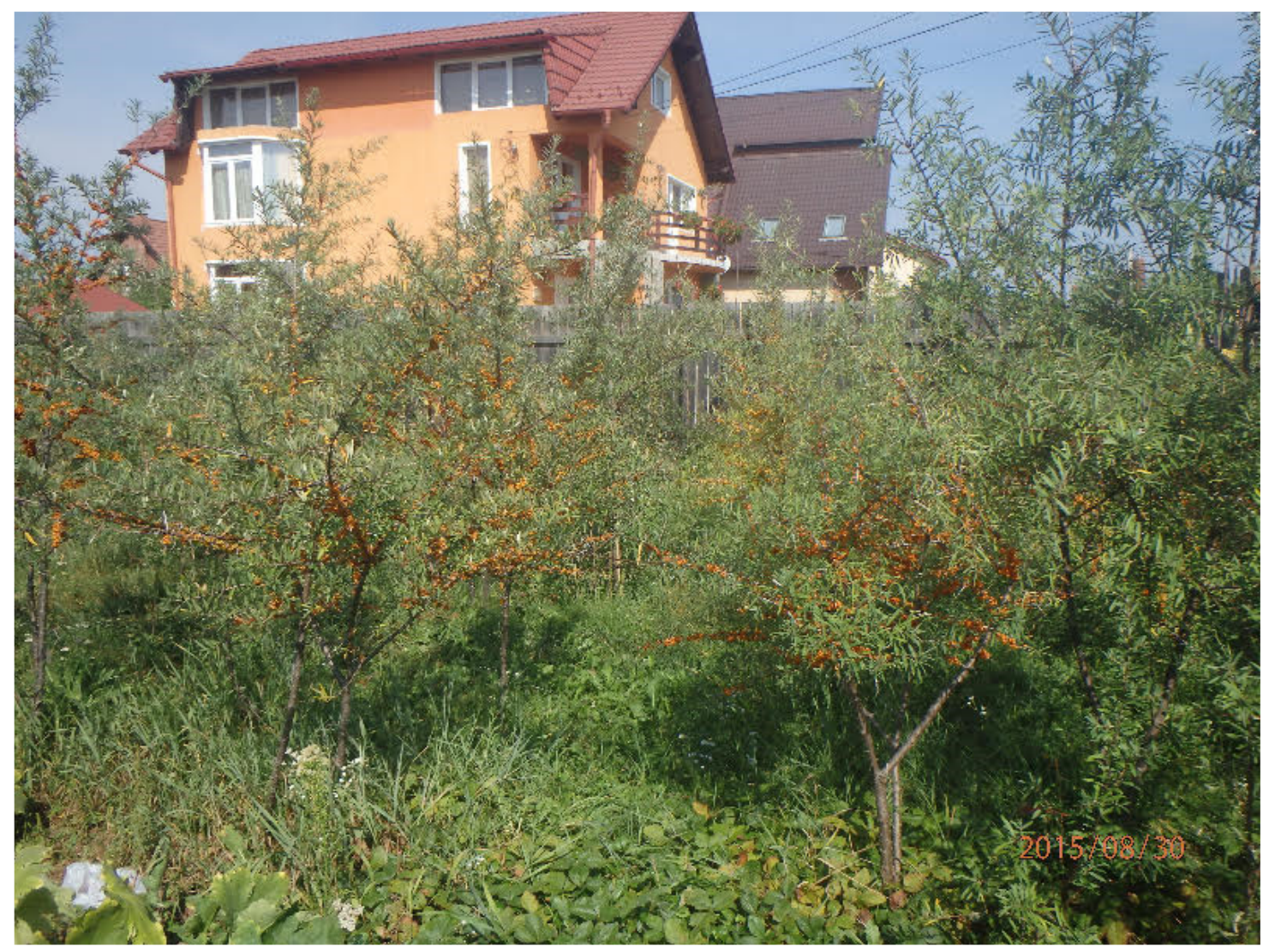

Fig. 3. H. salicifolia fructification of 5-year-old seedlings 
Chemical properties of H. salicifolia fruits

The chemical properties of fresh $H$. salicifolia fruits are shown in Table 1 and the chemical properties of $H$. salicifolia fruits preserved for 1 year and 5 months as well as H. rhamnoides preserved for 7 months are shown in Table 2.

From the data shown in Table 1, high variability regarding the quantity of total carotenoids (coefficient of variation, $\mathrm{CV}=38.87)$, vitamin $\mathrm{C}$ concentration $(\mathrm{CV}=$
24.01), and homogeneity with respect to the quantity of polyphenols $(\mathrm{CV}=11.93)$ can be seen.

UV-Vis spectral fingerprinting and total carotenoid content

The comparative UV-VIS spectra are presented in Fig. 4 , as well as the calculation of the carotenoid concentration in the extracts according to the formula generated by Britton et al. (1995).

Table 1. Chemical properties of fresh Hippophae salicifolia fruits

\begin{tabular}{|c|c|c|c|}
\hline Sample name & $\begin{array}{l}\text { Total carotenoids } \\
(\mathrm{mg} / 100 \mathrm{~g} \text { sample })\end{array}$ & mg polyphenols / $100 \mathrm{~g}$ sample & $\begin{array}{c}\text { Vitamin C concentration } \\
\text { (mg ascorbic acid / } 100 \mathrm{~g} \text { sample) }\end{array}$ \\
\hline H. salicifolia, V 1.1 . & 35.18 & 715.629 & 197 \\
\hline H. salicifolia, V 1.2. & 45.45 & 904.092 & 314 \\
\hline H. salicifolia, $\mathrm{V} 1$, average & 40.32 & 809.86 & 255.50 \\
\hline H. salicifolia, V 2.1 . & 19.64 & 740.272 & 202.5 \\
\hline H. salicifolia, V 2.2 . & 22.51 & 883.801 & 211.25 \\
\hline H. salicifolia, V 2, average & 21.08 & 812.04 & 206.88 \\
\hline H. salicifolia, average & 30.70 & 810.95 & 231.19 \\
\hline Coefficient of variation & 38.87 & 11.93 & 24.01 \\
\hline
\end{tabular}

Table 2. Chemical properties of preserved sea buckthorn fruits

\begin{tabular}{|c|c|c|c|c|}
\hline \multirow{2}{*}{ Characteristic } & \multicolumn{3}{|c|}{ Values } & \multirow{2}{*}{$\begin{array}{l}\text { Autochthon reference values } \\
\text { (H. rhamnoides) }\end{array}$} \\
\hline & Minimal & Maximum & Average & \\
\hline \multicolumn{5}{|c|}{ Vitamin C content ( $\mathrm{mg} / 100 \mathrm{~g}$ fruits) } \\
\hline & & & & -For fresh fruits: 100-200 (240) mg \% (Brad et al., 2002; \\
\hline & & & & Beldeanu, 2004); 66-142 mg\% (Pascanut et al., 2010b); \\
\hline -H. salicifolia & 221.27 & 227.64 & 223.56 & -for raw juice: 71.85-214.00 mg\% (Beldeanu, 1975; Brad \\
\hline -H. rhamnoides & 33.89 & 36.49 & 35.19 & et et al., 2002); \\
\hline & & & & $\begin{array}{l}\text {-for dry skim fruits: } 72.26-235.13 \mathrm{mg} \% \text { (Brad et al., } \\
\qquad 2002)\end{array}$ \\
\hline \multicolumn{5}{|c|}{$\begin{array}{l}\text { Total acidity } \\
\text { (g acid/100 g juice) }\end{array}$} \\
\hline $\begin{array}{l}\text {-H. salicifolia } \\
\text {-H.rhamnoides }\end{array}$ & $\begin{array}{l}2.68 \\
3.22\end{array}$ & $\begin{array}{l}3.54 \\
3.40\end{array}$ & $\begin{array}{l}3.04 \\
3.28\end{array}$ & $\begin{array}{l}\text { - For fresh fruits: } 2.33-2.55 \mathrm{~g} \%(\mathrm{Brad} \text { et al., } 2002) \text {; } \\
\text { - for the juice from fresh fruits: } 2.58-3.50 \mathrm{~g} \%(\mathrm{Brad} \text { et al., } \\
\text { 2002); } 2.77-4.58 \text { (Pascanut } \text { et al., 2010a); } \\
\text { - for dry unskimmed fruits: } 6.30-15.32 \mathrm{~g} \%(\mathrm{Brad} \text { et al., } \\
\text { 2002). }\end{array}$ \\
\hline \multicolumn{5}{|c|}{ Content of dry soluble substance (\%) } \\
\hline $\begin{array}{l}\text {-H. salicifolia } \\
\text {-H. rhamnoides }\end{array}$ & & & $\begin{array}{l}18 \\
9.8\end{array}$ & $\begin{array}{l}\text {-For fresh fruits: } 17.7-21.4 \% \text { (Beldeanu, 1975); } \\
\text {-for raw juice: } 11.0-13.31 \% \text { (Beldeanu, 1975) and 7.0- } \\
\text { 10.5\% (Pascanut et al., 2010). }\end{array}$ \\
\hline \multicolumn{5}{|c|}{$\begin{array}{l}\text { Inverted sugar content } \\
\qquad(\% \text { of juice })\end{array}$} \\
\hline $\begin{array}{l}\text {-H. salicifolia } \\
\text {-H. rhamnoides }\end{array}$ & $\begin{array}{l}1.36 \\
1.36\end{array}$ & $\begin{array}{l}1.75 \\
2.11\end{array}$ & $\begin{array}{l}1.58 \\
1.61\end{array}$ & $\begin{array}{l}\text {-For dry fruits: } 0.47-0.53 \% \text { (Brad et al., 2002); } \\
\text {-for juice: } 0.42 \% \text { (Brad et al., 2002); 1.75-.9.74\% } \\
\text { (Pascanut et al., 2010a). }\end{array}$ \\
\hline \multicolumn{5}{|c|}{ Lipids and pro-vitamin A extract in petroleum ether (\% dry substance) } \\
\hline $\begin{array}{l}\text {-H. salicifolia } \\
\text {-H. rhamnoides }\end{array}$ & & & $\begin{array}{l}0.56 \\
2.12\end{array}$ & $\begin{array}{l}\text {-For fresh fruits: } 4-9 \% \text { (Beldeanu, } 1975) ; \\
\text {-for fruits after two refrigeration months: } 0.14-0.72 \% \\
\text { (Dinulica, personal data); } \\
\text {-for raw juice: } 1-3 \% \text { (Beldeanu, 1975). }\end{array}$ \\
\hline \multicolumn{5}{|c|}{ Ash (\% dry substance) } \\
\hline $\begin{array}{l}\text {-H. salicifolia } \\
\text {-H. rhamnoides }\end{array}$ & & & $\begin{array}{l}0.205 \\
0.138\end{array}$ & -For fresh fruits: $0.65-0.70 \%$ (Brad et al., 2002). \\
\hline
\end{tabular}


Concentration of carotenoids in the samples analysed
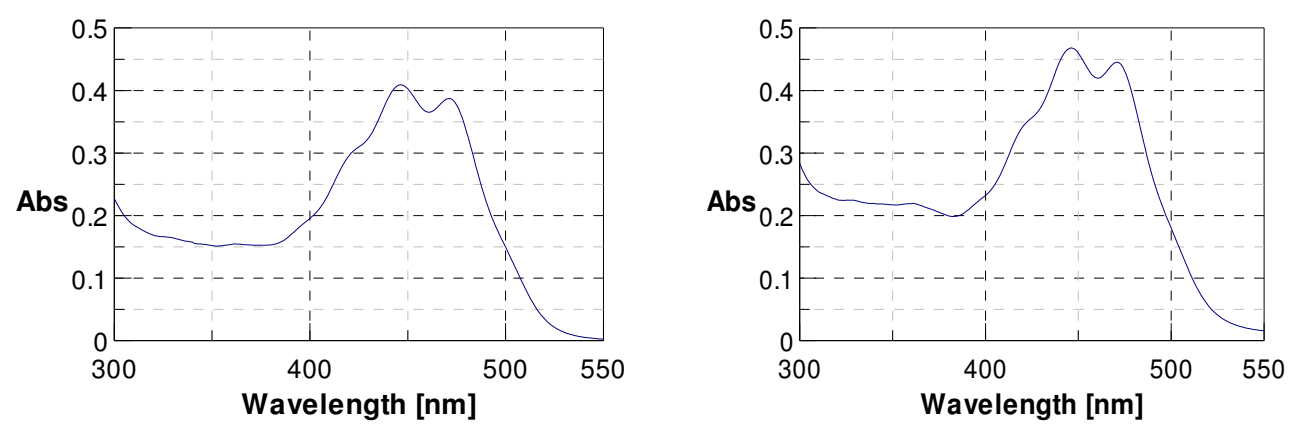

V11, dil. 1:10,

$\mathrm{DO}=0,40911$

V12, dil. 1:10,

$\mathrm{DO}=0,46806$

V11: $38.65 \mathrm{mg} / 100 \mathrm{~g}$

V12: $44.6 \mathrm{mg} / 100 \mathrm{~g}$

Mean value $=41.62 \mathrm{mg} / 100 \mathrm{~g}$

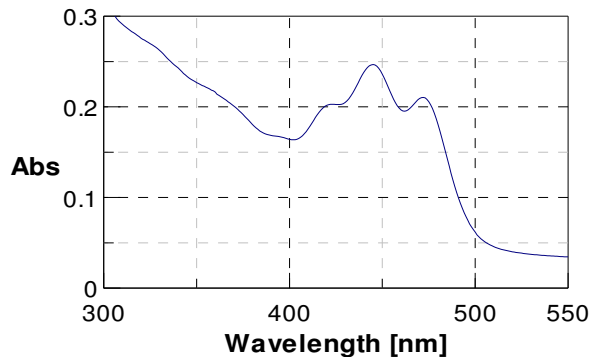

V21, dil. 1:10,

$\mathrm{DO}=0.21881$

V22, dil. 1:10,

$\mathrm{DO}=0.24614$

$\mathrm{V} 21: 20.66 \mathrm{mg} / 100 \mathrm{~g}$

V22: $23.55 \mathrm{mg} / 100 \mathrm{~g}$

Mean value $=22.11 \mathrm{mg} / 100 \mathrm{~g}$

Fig. 4. Comparative UV-Vis spectral fingerprints of the HS extracts (V11, V12, V21, V22)

Chromatographic fingerprinting $H P L C-D A D$ and UHPLC-TOF-ESI+-MS

The comparative HPLC-DAD chromatograms of samples V11 and V21 are presented in Fig. 5. The fingerprints are different, showing qualitative and quantitative differences between these samples. Generally, carotenoid molecules are separated at retention times (TR) between 15.4 and $20 \mathrm{~min}$. The peaks are visible at 445 and $475 \mathrm{~nm}$ wavelengths, which are specific for xanthophylls (zeaxanthin, lutein), beta and alpha-carotenes and lycopene, respectively.
Table 4 includes the main carotenoids separated from these extracts, identified after a preliminary calibration with pure standards, as well their percentage, calculated from the peak areas. The qualitative and quantitative composition of V12 and V21 is slightly different, the first sample being more concentrated in beta and alpha carotene, as well xanthophylls (especially zeaxanthin), while the second one being relatively concentrated in lycopene. The total carotenoid concentration was also different, the first sample being around 2 times more concentrated in carotenoids pigments.

Table 3. Vitamin content of H. salicifolia fruits (Lu, 1992)

\begin{tabular}{|c|c|c|c|c|}
\hline Comparison of the vitamin contents $(\mathrm{mg} / 100 \mathrm{~g})$ of $H$. salicifolia and & Vitamin & Vitamin & Vitamin & Vitamin \\
\hline others species & A & B1 & B2 & C \\
\hline Hippophae salicifolia & 11.00 & 0.04 & 0.56 & $300-1600$ \\
\hline Cilicrosa roxburghii & 4.83 & 0.05 & 0.03 & $1000-3000$ \\
\hline Hawthorn & 0.82 & 0.02 & 0.05 & $100-150$ \\
\hline Orange & 0.55 & 0.08 & 0.03 & 50.0 \\
\hline Tomato & 0.31 & 0.03 & 0.02 & 11.8 \\
\hline Carrot & 4.00 & 0.02 & 0.05 & 8.0 \\
\hline
\end{tabular}

Table 4. Retention times (tR, min), carotenoids separated and identified by HPLC-DAD technique in samples V11 and V21

\begin{tabular}{ccccc}
\hline & Sample V11 & & \multicolumn{2}{c}{ Sample V21 } \\
\hline $\mathrm{t}_{\mathrm{R}}(\mathrm{min})$ & Carotenoid identified & $\%$ & $\mathrm{t}_{\mathrm{R}}(\mathrm{min})$ & Carotenoid identified \\
\hline 15.5 & Lutein & 12 & 15.5 & Lutein \\
15.8 & Zeaxanthin & 16 & 15.8 & Zeaxanthin \\
16.8 & Beta-cryptoxanthin & 12 & 16.8 & Beta-cryptoxanthin \\
18.0 & Alpha-carotene & 20 & 13.0 & Alpha-carotene \\
18.4 & Beta-carotene & 22 & 18.4 & Beta-carotene \\
18.9 & Lycopene & 18 & 18.9 & Lycopene \\
20.0 & NI & - & 20.0 & NI \\
\hline
\end{tabular}



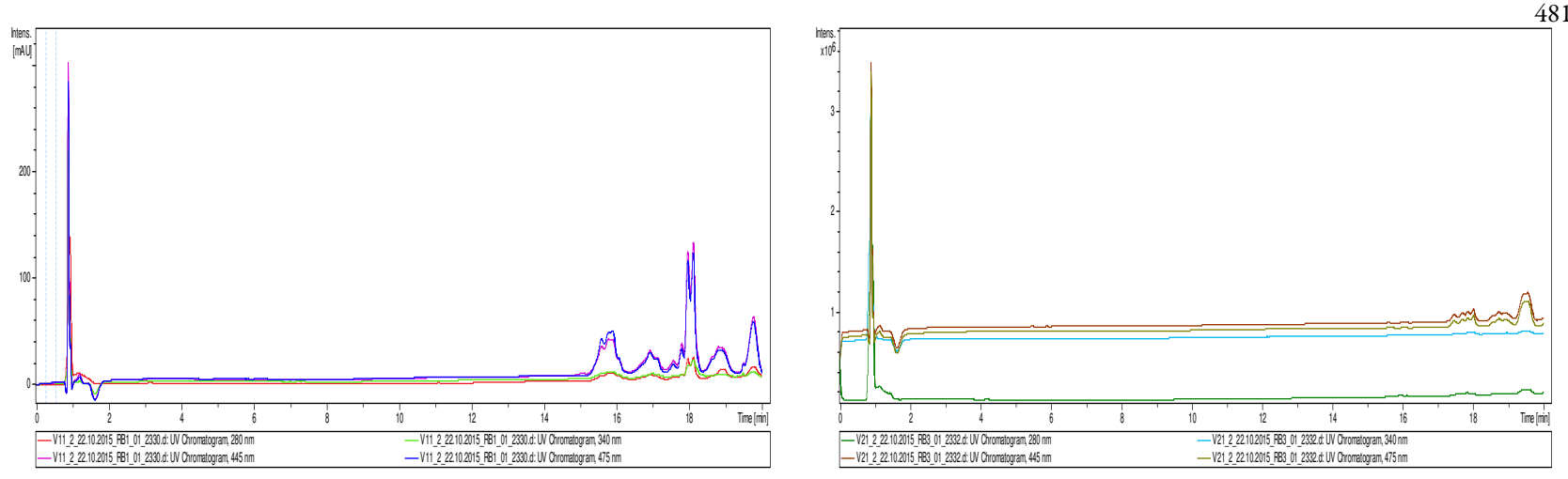

Fig. 5. Comparative HPLC-DAD chromatographic fingerprints of the HS extracts: V11 (left) and V21 ( right)

\section{Discussion}

The vitamin $\mathrm{C}$ content of $H$. salicifolia fruits is much higher than that in $H$. rhamnoides fruits: $231 \mathrm{mg}$ ascorbic $\mathrm{acid} / 100 \mathrm{~g}$ sample in comparison with 100-200 (240) $\mathrm{mg} \%$ (Brad et al., 2002; Beldeanu, 2004) and 66-142 $\mathrm{mg} \%$ (Pascanut et al., 2010b), if we refer only to the analyses performed in Romania.

From the data shown in (Table 2), it can be observed that $H$. salicifolia fruits do not lose, except for a small amount, their vitamin $\mathrm{C}$ content if they are maintained at lower temperatures (i.e., in a freezer) even over long periods of time. Based on our data, the differences between fresh fruits and those preserved for 1 year and 5 months ranged from 231 to $224 \mathrm{mg}$ vitamin C/100 g. Moreover, the fruits kept in the freezer for longer periods of time still have a superior vitamin $\mathrm{C}$ content $(224 \mathrm{mg} / 100 \mathrm{~g})$ in comparison with $H$. rhamnoides fresh fruit $(100-200 \mathrm{mg} / 100 \mathrm{~g})$.

There are significant differences in vitamin $\mathrm{C}$ content between $H$. salicifolia and $H$. rhamnoides preserved fruits: the $H$. salicifolia fruits maintained a relatively constant vitamin $\mathrm{C}$ content over long period of preservation, and this number is approximately seven times higher than $H$. rhamnoides. The other fruit characteristics do not register significant differences. Previous studies have also recorded a decrease in vitamin C content for White Sea Buckthorn (from 135 to $102 \mathrm{mg} / \mathrm{kg}$, after preservation for 90 days after the fruits underwent a process of refrigeration between $0{ }^{\circ} \mathrm{C}$ and $5{ }^{\circ} \mathrm{C}$ for $1-2$ days, and were then frozen at $-15^{\circ} \mathrm{C}$; Pășcănuț et al., 2010b).

As previously discussed in the literature, there is variability in the chemical composition of $H$. salicifolia fruits among different plant populations (Ahmad et al., 2005). Furthermore, the concentration of vitamin $\mathrm{C}$ in $H$. rhamnoides was highly variable among different populations (Karhu et al., 1999). The results obtained in this study regarding vitamin $\mathrm{C}$ concentration in $H$. rhamnoides fruits (231 and $224 \mathrm{mg} / 100 \mathrm{~g}$ for fresh and frozen fruits, respectively) are similar with those obtained in previous studies [196 mg/100 g (Ahmad et al., 2005)], but lower than those obtained by Kaushal et al. (2013) (490.5 mg/100 g), Rongsen (1992) (from 200-1500 mg/100 g), or Pant et al. $(2014)$ (2984 mg/100 g).

$H$. salicifolia fruits have a much higher vitamin $\mathrm{C}$ content $(2984 \mathrm{mg} / 100 \mathrm{~g})$ than $H$. tibetana, H. rhamnoides, or even Citrus sinensis $(879,230$, and $50 \mathrm{mg} / 100 \mathrm{~g}$, respectively). As can be observed in the values in (Table 3), $H$. salicifolia is richer in vitamins $\mathrm{C}, \mathrm{B} 2$, and $\mathrm{A}$ than hawthorn, orange, tomato, or carrot.

The carotenoid quantities determined in this study in the $H$. salicifolia fresh fruits $(30.7 \mathrm{~g} / 100 \mathrm{~g})$ are slightly higher than the ones obtained by Kaushal et al. (2013) $(18.3$ $\mathrm{mg} / 100 \mathrm{~g})$. Major carotenoid pigments include $\delta$ and $\beta$ carotene, lycopene flavaxanthin, progestin, kryptoxanthin, violaxanthin, and neoxanthin (Ranjith et al., 2006; Beveridge et al., 1999; Xing, 2003).

The polyphenol quantity determined in this study in $H$. salicifolia fresh fruits $(811 \mathrm{mg} / 100 \mathrm{~g})$ is higher than that determined by Pant et al. (2014) for $H$. salicifolia (591 $\mathrm{mg} / 100 \mathrm{~g})$. The same authors indicated that there exists a higher concentration of polyphenols in $H$. salicifolia fruits than for $H$. tibetana and $H$. rhamnoides (572 and 521 $\mathrm{mg} / 100 \mathrm{~g}$, respectively). Higher phenolic content in $H$. salicifolia compared with $H$. rhamnoides has been confirmed in previous studies (Sharma et al., 2013; Ranjith et al., 2006).

Total acidity of the fruit determined in this study (3.04 $\mathrm{g} / 100 \mathrm{~g})$ was similar to values determined by Brad et al. (2002) and Kaushal et al. (2013) (2.33-2.55 and $2.7 \mathrm{~g} / 100$ $\mathrm{g}$, respectively).

The sugar content for fresh fruits determined in our investigations $(1.58 \%)$ is situated within the limits obtained by other researchers: $0.5 \%$ (Brad et al., 2002) and 6.29\% (Dwivedi et al., 2006).

\section{Conclusions}

As a highly adaptable plant that grows in varied conditions of climate and soil, abundant in compounds, nutritive and bioactive substances, Hippophae salicifolia has numerous usages in industries as varied as medicine, cosmetics or soil sciences. The aim of this paper was to ascertain its numerous properties, focusing on its chemical propertis and to offer future directions.

As such, sowing, cultivating and managing $H$. salicifolia cultures do not pose considerable problems. Based on our analysis, the best cultures are realized during the spring, at a depth of $2 \mathrm{~cm}$, with a seed norm of $2 \mathrm{~g}$ per linear meter, or a substratum composed of a mixture of peat and sand. Three years from planting, the plant's dimensions were as follows: minimum height, $120 \mathrm{~cm}$; maximum height, $260 \mathrm{~cm}$; average height, $170 \mathrm{~cm}$; and crown diameter, minimum 85 - 
482

$90 \mathrm{~cm}$ and maximum $200 \mathrm{~cm}$. Another aspect revealed by our study is that forming cuttings in the crown is a necessary measure for obtaining maximal fructification. The comparison with $H$. rhamonides has helped us in emphasizing the properties and advantages of creating and sustaining $H$. salicifolia cultures.

The higher content of vitamin C (231 mg ascorbic $\mathrm{acid} / 100 \mathrm{~g}$ sample) preserved and even increased in comparison with $H$. rhamonides (224 vs. $100-150 \mathrm{mg} / 100$ $\mathrm{g})$ if the species are kept in proper conditions, recommend the species for cultivation. Insignificant differences were obtained for other chemical characteristics, including total acidity, inverted sugar content, and concentration of dry substances. We observed also variability in the chemical composition of $H$. salicifolia fruits among different plant populations.

As such, the culture of $H$. salicifolia species in Europe is possible (on different field categories, especially degraded fields) and even recommended due to its ability to fix and enrich the soil, but especially because of the multiple uses of its fruits, leaves, or wood.

\section{References}

Airi S, Bhatt ID, Bhatt A, Rawal RS, Dhar U (2009). Variations in seed germination of Hippophae salicifolia with different pre-soaking treatments. Journal of Forestry Research 20(1):27-30.

Andersson SC, Olsson ME, Johansson E, Rumpunen K (2009). Carotenoids in sea buckthorn (Hippophae rhamnoides L.) berries during ripening and use of pheophytin as a maturity marker. Journal of Agricultural and Food Chemistry 57:250-258.

Bal LM, Meda V, Naik SN, Satya S (2011). Sea buckthorn berries: A potential source of valuable nutrients for nutraceuticals and cosmoceuticals. Food Research International 44:1718-1727.

Basistha BC, Sharma NP, Lepcha L, Arrawatia ML, Sen A (2009). Ecology of Hippophae salicifolia $\mathrm{D}$. Don of temperate and sub-alpine forests of North Sikkim Himalayas - a case study.Symbiosis 50(1-2):87-95.

Beldeanu EC (1975). Cercetări privind fructificarea și proprietățile unor produse primare obținute din fructe la cătina albă (Hippophaëramnoides L.) [Investigations regarding the fructification and properties of some primary products obtained from white sea buckthorn fruits]. $\mathrm{PhD}$ thesis abstract, Braşov University, pp 16-21.

Beldeanu EC (2004). Specii de interes sanogen din fondul forestier [Forest fund species of sanogen interest]. Editura Universitatii Transilvania, Braşov pp 39-50.

Beveridge T, Li TSC, Oomah BD, Smith A (1999). Seabuckthorn products: manufacture and composition. Journal of Agricultural and Food Chemistry 47:3480-3488.

Brad I, Brad IL, Radu F (2002). Cătina albă, o farmacie într-o plantă [White sea buckthorn, a pharmacy in a plant]. Editura Tehnica București pp 4183.

Britton GS, Liaaen J, Pfander H (1995). Carotenoids, vol 1B: Spectroscopy. In: Britton et al.(Eds). Birkhäuser Verlag,Zurich.

Constandache C, Peticilă A, Dincă L, Vasile D (2016). The usage of Sea Buckthorn (Hippophae Rhamnoides L.) for improving Romania's degraded lands. AgroLife Scientific Journal 5(2):50-58.
Corlățeanu S, Ştefănescu E, Beldeanu EC (1975). Practical handbook on forest accessory products. University of Braşov Publishing House, pp 5355.

Daviers MB, Austin J, Partridge DA (1991). Vitamin C - Its chemistry and biochemistry. The Royal Society of Chemistry, Thomas Graham House, Cambridge.

Dincă L, Dincă M, Şerbănescu A, Stanca A, Darie G, Prisecaru T, Ciobanu V, Pătruț I (2011). Reconstrucția haldelor de steril prin utilizarea de specii cu potential energetic [The reconstruction of waste heaps by using species with energetic potential]. EdituraSilvica, București.

Dwivedi SK, Singh R, Ahmed Z (2006). The Seabuckthorn. Field research laboratory. Defence Research and Development Organization (DRDO).Leh(Ladakh)-194101 (JandK).India.

Gaur RD (1999). Flora of the District Garhwal, North West Himalaya University ofChicago, Transmedia.

Geetha S, Asheesh G (2011). Medicinal and therapeutic potential of Sea buckthorn (Hippophae rhamnoides L.). Journal of Ethnopharmacology 138(2011):268-278.

Giuffrida D, Pintea A, Dugo P, Torre G, Pop RM, Mondello L (2011). Determination of carotenoids and their esters in fruits of sea buckthorn (Hippophae rhamnoides L.) by HPLC-DAD-APCI-MS. Phytochemical Analysis 23:267-273.

GuptaSM,AhmedZ(2010). Seabuckthorn (Hippophaesalicifolia L.) plant: As source donor of cold tolerant genes for improving high altitude agriculture during cold stress. Research in Environment and Life Sciences3(3):105-112.

Gupta SM, Grover A, Pandey P, Ahmed Z (2012). Female plants of Hippophae salicifolia D. Don are more responsive to cold stress than male plants. Physiology and Molecular Biology of Plants 18(4):377-380.

Gupta SM, Gupta A, Ahmed Z, Kumar A (2011a). Antibacterial and antifungal activity in leaf, seed extract and seed oil of sea buckthorn (Hippophae salicifolia D. Don) plant. Plant Pathology and Microbiology 2(2):1-4.

Gupta SM, Pandey P, Grover A, Ahmed Z (2011b). Breaking seed dormancy in Hippophae salicifolia, a high value medicinal plant. Physiology and Molecular Biology of Plants 17(4):403-406.

Kallio H, Yang B, Peippo P, Tahvonen R, Pan R (2002). Triacylgycerols, gycerophospholipid, tocopherols, and tocotrienols in berries and seeds of two subspecies (ssp. sinensis and mongolica) of sea buckthorn (Hippophaë rhamnoides). Journal of Agricultural and Food Chemistry 50:30043009.

Kallner A (1987). Requirement for vitamin C based on metabolic studies. Annals of the New York Academy ofSciences 498(1):418-423.

Karhu ST, Vlvinen SK, Hagg M, Ahvenainen R, Evers AM, Tiilikkala K (1999).Vitamin C: a variable quantity factor in Sea buckthorn breeding. Agriculture Food Quality II: quality management of fruits and vegetables, from field to table. Turku, Finland, 22-25 April. Royal Society ofChemistry, Cambridge, UK, pp 360-362.

Kaushal M, Sharma PC, Sharma R(2013). Formulation and acceptability of foam mat dried seabuckthorn (Hippophae salicifolia) leather. Journal of Food Science and Technology 50(1):78-85.

Lu SS, Uang BJ (1992). Asymmetric Synthesis of $\alpha$-Amino Acids from Glycine. Journal of the Chinese Chemical Society39(3):245-249. 
Matheus A, MacLeod L (1994). Cognitive approaches to emotion and emotional disorders. Annual Review of Psychology 45:25-50.

McDonald EJ, Turcotte AL (1946). Study of Ofne's method for determination of invert sugar. Journal of Research of the National Bureau of Standards 37:429-434.

OECD (2009). Guidelines on objective tests to determine quality of fruits and vegetables, dry and dried produced. Retrieved September 01, 2016 from www. oecd.org.

Padwad Y, Ganju L, Jain M, Chanda S, Karan D, Banerjee PK, Sawhney RC (2006). Effect of leaf extract of Seabuckthorn on lipopolysaccharide induced inflammatory response in murine macrophages. International Immunopharmacology 6(1):46-52.

Pant M, Lal A, Rani A (2014). Hippophae salicifolia D. Don - A plant with multivarious benefits. International Journal of Pharmacy and Pharmaceutical Sciences 6(11):37-40.

Pârlog RM, Vodnar DC, Dulf FV, Leopold L, Socaciu C (2009). HPLCPDA and UV-Vis spectrometry used to fingerprint sea buckthorn (Hippophae rhamnoides L.) berries comparatively with leaves and seeds extracts. Bulletin UASVM Agriculture 66:409-414.

Păşcănuţ I, Pop MR, Danciu I (2010a). Determining the soluble dry substance, acidity, sugar contents directly and totally reduced from the Sea buckthorn (Hippophae rhamnoides L.) juice. Journal of Horticulture, Forestry and Biotechnology 1:123-125.

Păşănuţ I, Pop MR, Danciu I (2010b). Determining vitamin C quantity from Sea buckthorn fruits (Hippophae rhamnoides L.) during harvest and cold storage. Journal of Horticulture, Forestry and Biotechnology 1:126-128.

Pintea A, Varga A, Stepnowski P, Socaciu C, Culea M, Diehl HA (2005). Chromatographic analysis of carotenol fatty acid esters in Physalis alkekengi and Hippophae rhamnoides. Phytochemical Analysis 16:188195.

Pop RM, Weesepoel Y, Socaciu C, Pintea A, Vincken JP, Gruppen H (2013). Carotenoid composition of berries and leaves from six Romanian sea buckthorn (Hippophae rhamnoides L.) varieties. Food Chemistry 147:1-9.

Raffo A, Paoletti F, Antonelli M (2004). Changes in sugar, organic acid, flavonol and carotenoid composition during ripening of berries of three seabuckthorn (Hippophae rhamnoides L.) cultivars. European Food Research and Technology 219:360-368.

Ranjith A, Sarin Kumar K, Venugopalan VV, Arumughan C, Sawhney RC, Singh V (2006). Fatty acids, tocols, and carotenoids in pulp oil of three sea buckthorn species (Hippophae rhamnoides, H. salicifolia, and H. tibetana) grown in the Indian Himalayas. Journal of the American OilChemists' Society 83(4):359-364.

Rongsen A (1992). Sea buckthorn: multi-purpose plant species for fragile mountains. ICIMOD Occasional Paper No. 20, Kathmandu, Nepal, pp 6-7 and 18-20.
Saikia M, Handique PJ (2012). Antioxidant and antibacterial activity of leaf, bark, pulp and seed extracts of seabuckthorn (Hippophae salicifolia D. Don) of Sikkim Himalayas. Journal of Medicinal Plants Research 7(19):1330-1338.

Sankhyan HP, Sehgal RN, Bhrot NP (2005). Standardization of presowing treatments for different seabuckthorn species in cold deserts of Himachal Pradesh. Indian Forester 131(7):931-938.

Schuck KP, Dolivet A, Jeantet R (2012). Analytical methods for food and dairy powders. Wiley-Blackwell, pp 113-118.

Sharma P, Kirar V, Suryakumar G, Mishra K (2013). Phytochemical analysis of Sea buckthorn extracts and quantification of flavonoids by HPTLC. Biochemistry \& Pharmacology 2(4):73-78.

Sinclair WB, Bartholomew ET, Ramsey RC (1945). Analysis of organic acids of orange juice. Plant Physiology 20(1):3-18.

Singh R, Rastogi S, Dwivedi U (2010). Phenylpropanoid Metabolism in Ripening Fruits. Comprehensive Reviews in Food Science and Food Safety $9(4): 398-416$.

Singh V (2003). A multipurpose wonder plant. In: Seabuckthorn (Hippophae L.) Singh V(Ed).India: Daya Publishing House pp 3-69.

Socaciu C (2008). Food colorants: Chemical and functional properties. CRC Press-Taylor and Francis Group, New York.

Synge PM (1974). Dictionary of gardening: a practical and scientific encyclopedia of horticulture (2ndEdition). Clarendon Press, Oxford.

Uprety Y, Asselin H, Boon E, Yadav S, Shrestha K (2010). Indigenous use and bio-efficacy of medicinal plants in the Rasuwa Distric, central Nepal. Journal of Ethnobiology and Ethnomedicine 6:3.

Vasile D, Dincă L, Voiculescu I (2015). Collecting medicinal plants from spontaneous flora of forest fund managed by National Forest Administration Romsilva. Revista de Silviculturăși Cinegetică 37:88-94.

Vasile D, Dincă L, Voiculescu I (2016). Wild berries collected in 2016 from national forest fund managed by RNP Romsilva. Revista de Silvicultură şiCinegetică 38:72-75.

Vescan A, Pamfil D, Bele C, Matea C, Sisea CR (2010). Several lipophilic components of five elite genotypes of Romanian seabuckthorn (Hippophae rhamnoides subs. carpatica). Notulae Botanicae Horti Agrobotanici Cluj-Napoca 38:114122.

Xing C (2003). Health protection and processing technology of seabuckthorn tea. In: Singh V (Ed). Seabuckthorn (Hippophae L.) - A multipurpose wonder plant. Indus Publishing Company pp 475-478.

Yang B, Kallio H (2005). Lipophilic components of seabuckthorn (Hippophae rhamnoides L.) seeds and berries. In: Singh V (Ed). Seabuckthorn (Hippophae L.) - A multipurpose wonder plant. Indus Publishing Companypp 70-97.

Yao Y, Tigerstedt PMA (1994). Genetic diversity in Hippophae L. and its use in plant breeding. Euphytica 77:165-169.

*** (2011). Procedures for analysis of citrus products, 6th ed. JBT Food Tech Citrus Systems. 